\title{
The 'blind spot' of agricultural research: Labour flexibility, composition and worker availability in the South West of England
}

\author{
Caroline Nye*
}

Centre for Rural Policy Research (CRPR), Lazenby House, Prince of Wales Road, University of Exeter, EX4 4PJ, Exeter, United Kingdom

\begin{abstract}
Agriculture in the UK faces a number of long-term challenges as the global marketplace continues to expand, world population grows, and an increasing pressure is exerted upon natural resources. It needs to ensure its place as a competitive, resilient, and environmentally sustainable industry both locally and in the global arena. A key constraint which ties in with all of the above is the availability of labour. Both governmental departments in their statistical analyses of agriculture in the country, as well as academic research, largely ignore the existence of certain actors performing farm labour who are not the farmer, particularly agricultural contractors, and as a result, have missed the emergence of significant patterns occurring within the farm workforce. Accuracy of data concerning labour use in agriculture has, therefore, been extremely limited. This paper identifies the composition of labour on farm holdings in the South West of England today and recognises the increasing prevalence of flexible labour sources. It determines both current and anticipated future staffing needs of the holdings studied, which provides an indicator as to the gravity of agriculture's labour crisis in the South West.
\end{abstract}

Keywords: agriculture / labour / flexible workforce / contractors

Résumé - «L'angle mort » de la recherche en agriculture : la flexibilité de l'emploi et la disponibilité des travailleurs dans le sud-ouest de l'Angleterre. L'agriculture de Grande-Bretagne fait face à plusieurs défis sur le long terme, dans un contexte d'expansion continue du marché mondial, de croissance démographique et de pressions croissantes exercées sur les ressources naturelles. L'agriculture anglaise doit affirmer sa place comme secteur compétitif, performant, et respectueux de l'environnement, au niveau local et mondial. La disponibilité de la main-d'œuvre agricole est une contrainte majeure pour lancer ces changements. Les analyses statistiques sur l'agriculture effectuées par les organismes gouvernementaux et la communauté scientifique ne tiennent pas compte de certains acteurs du marché du travail, délaissant ainsi l'apparition d'acteurs significatifs. Les données concernant l'utilisation de la main-d'œuvre agricole manquent de précision. Ce document identifie la composition de la main-d'œuvre actuellement disponible pour les exploitations agricoles du sud-ouest de l'Angleterre et détermine les besoins actuels et futurs en effectifs dans ces exploitations, ce qui fournit un indicateur de la gravité d'une «crise de main-d'œuvre» dans le Sud-Ouest anglais

Mots clés : agriculture / travail / main-d'œuvre flexible / employeur

\section{Introduction}

The decline of the agricultural labour force has been a familiar trope in both early and contemporary discussions around British agriculture. Although this decline is inarguable, both governmental departments, in their statistical analyses of agriculture in the UK, as well as academic research, tend to ignore certain actors performing farm labour who are neither

*Corresponding author: c.nye@exeter.ac.uk farmers nor seasonal workers. This applies particularly to agricultural contractors who form a significant part of the flexible labour market where part-time, self-employed or temporary workers have become increasingly prevalent in the farming world today.

While historical and recent statistics reveal that fundamentally the number of farm workers has fallen drastically, they fail to describe the transition of some of these individuals from farm employees/owners to agricultural contractors; an indirectly-employed cohort which, according to Body (1983), had 'increased just as drastically' as the decline in permanent 
workforce during this period (ibid.: 42). As a result, accuracy of data concerning labour use in agriculture remains extremely limited (Ball, 1987b). Since this recognition in the 1980s, little further research has developed.

From the mid-1990s, a significant period that saw fluctuations in exchange rates, a fall in world prices and a continuation of reforms in the Common Agricultural Policy (CAP), the survival of many farms has become increasingly reliant on family labour (Lobley and Potter, 2004) resulting, until recently, in a continuation in the decline of permanent workers that began in the 1850s. Often not sufficient for seasonal peak labour requirements however, family farms and larger holdings frequently require augmenting with seasonal, casual and/or agricultural contractor arrangements. The existence of contractors in agriculture permits 'the efficient and timely completion of key field operations without the need to take on extra staff or buy expensive machinery' (Defra, 2014: 2).

It is important to understand the key changes in the agricultural workforce. Primarily, therefore, the importance of flexibility is outlined, with the application of Atkinson's (1984) theoretical model of flexibility to the case of agriculture. This is followed by a description of the different workforce types making up the current labour force in the UK, and finally, current gaps in knowledge regarding the farm workforce are revealed.

\section{Agriculture and the flexible labour market}

An examination of post-war intermittent labour forms in agriculture in the UK recognised that 'the conception of the farm labour force as overwhelmingly full-time, regular (hired or family), and living on or near the place of work is no longer accurate' (Ball, 1987b): 133) and that regular labour forms so long associated with the British firm are being rapidly replaced by part-time, part-year labour, usually based off of the farm and sometimes from a separate locality entirely. More importantly, Ball identified that 'never have important segments of the labour force, such as directly-recruited intermittent workers [...] or agricultural contractors been subjected to detailed attention' (ibid.: 134). Since then, seasonal migrant workers have attracted noteworthy consideration (Scott 2007; Geddes and Scott, 2011), while literature on contractors remains sparse.

A certain level of flexibility has always been necessary in agriculture, according to Errington and Gasson (1996), due to above average 'peaking' or labour requirements at different points in the annual cycle. These peaks vary according to the farming system, but depend upon time-critical events such as hay and silage-making, harvesting, calving or lambing. In recent times, social and economic factors have contributed to a move towards greater flexibility in farming. Primarily, farmers seek to reduce production costs, utilising accessibility to numerical flexibility whilst ensuring that 'the permanent workforce is used to full capacity' (Errington and Gasson, 1996: 130). A peripheral labour force, that which is employed on a short-term basis, is recognised by Errington and Gasson as being cheaper than core workers, those members of a firm employed in more permanent positions. The importance of increased accessibility to a peripheral workforce has also arisen from the changes in the social structure in rural areas. Errington and Gasson (1996) describe the farming population as being thinner on the ground. Where historically, a neighbour may have assisted in times of emergency, similar levels of availability are now rare. They suggest this is also the case with potential family labour, where the availability of spouses or children has declined due to increased employment off-farm.

At face value, Atkinson's (1984) model of flexibility can be superimposed onto the traditional farming model, with family members and permanent employees representing the core; part-time, temporary, or casual labour providing numerical flexibility on the periphery; and self-employed or larger contracting firms forming the outermost layer of the model. Functional flexibility from within the core workforce is also required in response to changes in technology, as the development of new skills related to new technology becomes an essential job requirement (Errington and Gasson, 1996). A high degree of functional flexibility has always been prevalent in the agricultural industry as farm workers have been required to perform a plethora of tasks on a daily, monthly and seasonal basis. Contingent labour, however, especially contractors, can similarly fulfil this role, especially for smaller businesses that are 'denied access to specialised skills' (ibid.: 131). Numerical flexibility is also provided by core employees as farmers and farm workers alike rarely adhere to a forty hour week. Flexibility within agriculture has, therefore, become the norm.

\subsection{The workforce in agriculture}

Atkinson's model of flexible labour can be tailored to fit the agricultural workforce in the UK (Gasson and Errington, 1993) (Tab. 1). To some extent, all actors contributing to labour on a holding can be considered part of the flexible labour force, including family workers and permanent labour. This is due to the functional flexibility required of the regular workforce alongside requirements for numerical flexibility.

\subsection{Family labour}

Farmers and their families provide key input into the working hours and productivity of many farms and thus any definition of farm labour should always include this arrangement of workers. Holderness (1985) describes how 'in the division of labour on farms the old distinction between farmers and labourers has become blurred since the 1950s' (ibid: 122). Although many farmers have taken on a more managerial and/or entrepreneurial role, the manual, technological and administrative tasks are often spread between either just a farmer and his family, or the farming family and hired help, be it in the form of a more traditional farm worker or a contractor. Gasson and Errington (1993) produced a detailed study of The Farm Family Business, from which they discovered that as early as 1986 , hired workers were only employed on 28 per cent of UK farm holdings, compared to 40 per cent 26 years earlier, resulting in 72 per cent of UK farms relying on family labour (ibid.: 44). This figure discounts any reliance on agricultural contractors, an increasingly crucial labour contributor to the family farm. 
Table 1. Possible sources of farm labour.

Tableau 1. Sources possibles de main-d'œuvre sur l'exploitation.

\begin{tabular}{|c|c|c|c|}
\hline & Unpaid Labour & Labour which is either paid or unpaid & Paid Labour \\
\hline The regular workforce & Spouse & Other children & Part-time worker(s) \\
\hline \multirow{2}{*}{ The flexible workforce } & & Neighbours & Seasonal/casual workers \\
\hline & & Kin & Advisors/consultants \\
\hline
\end{tabular}

Source: Adapted from Gasson and Errington (1993: 119).

\subsection{The regular workforce}

Between 2005 and 2015, numbers of regular, hired farm workers have remained relatively stable in England, witnessing a slight decrease in full-time workers and no change in numbers of part-time workers (Defra, 2015). According to Defra's figures (2014), the number of regular full-time workers on commercial agricultural holdings in June 2014 in the whole of the UK totalled 64000 , and regular part-time workers totalled 40000 . Although a small proportion of the workforce as a whole, these numbers are significant as the future of farming in the UK comes under the lens, and thus the talent, skills and labour available to farms during what some consider a time of 'crisis' become more relevant than ever (Tipples and Morriss, 2002).

In spite of urgent calls by organisations such as Defra (2013), and the NFU (2015) relating to the lack of available workers with the relevant skills in agriculture today, research and literature relevant to this crisis is still severely lacking. Lobley et al. (2005) touch on it briefly in a longitudinal study of the wider social impacts of agricultural restructuring of agricultural businesses in six areas of the UK, stating that there was 'evidence from some of the discussion groups that labour shortages could be a problem either in terms of finding suitably skilled labour or large numbers of workers at key times' (ibid.: 17).

But rather than focussing on labour availability, any references made to the regular workforce in contemporary British literature have tended to focus on responses to the foot and mouth disease epidemic in rural populations (Mort et al., 2005), farm-related stress (Parry et al., 2005), organic-farming related labour (Morrison et al., 2005) or transitions in labour resulting from agricultural restructuring (Lobley et al., 2005). More in-depth studies regarding issues around labour shortages in agriculture generally seem to have been carried out outside of the UK, especially New Zealand (Tipples and Morriss, 2002) and Australia (Nettle, 2015).

\subsection{Seasonal/casual workers}

Many farms in the UK have become ever more dependent upon migrant workers who will work for a very low wage. Geddes and Scott (2011) ascertain that numerous farms now operate on a dual-labour market system, with a small core of permanent staff, augmented by a fluctuating and temporary workforce. This latter workforce forms the 'secondary labour market' and according to Geddes and Scott 'it is here where the least desirable and most insecure forms of employment are concentrated' (ibid.: 197). However, this perspective seems to point only to the relationship between gang masters and the migrant workers rather than other workers who might contribute to seasonal labour, such as students, WWOOFERS (World Wide Opportunities on Organic Farms - a volunteering scheme for workers in exchange for room and board), relief workers, or apprentices. Brexit is likely to impact the availability of seasonal labour in the form of migrant workers, potentially bringing some attention to the need to attract native workers into seasonal work. Seasonal labour shortages are well-documented (Devlin, 2016), therefore related actors do not represent the ignored cohorts described in this paper.

\subsection{Contractors}

The UK is recognised as the 'most developed country in Europe as regards agricultural contracting' by Igata et al. (2008: 29), who identify farm size, labour shortages, ownership of new technologies and cultural factors as variables which play important factors in decision-making processes around contracting. Peel and Boxall (2005) define a contractor as a worker who is 'operating as a business in their own right, who are not employing others' (ibid.: 1676). For the purpose of this paper, businesses operating as contractors who do or do not employ others will be considered a contractor, as contractor firms consist of both individual, self-employed workers as well as larger operations employing a number of people.

According to Ball (1987a) in his study of agricultural contractors, "the great majority of contracts involved both labour and machinery [...] and relatively few were labour-only contracts' (ibid.: 482). Brookfield (2008) states how outsourcing labour requirements to contractors allows family farmers 'the means to work larger areas without stretching their own labour resources', even though he suggests 'the quality and commitment of such labour remains inferior to that of the farm family' (ibid: : 120).

Generally, theories around flexible labour agree that core labour is usually internal and equal to primary labour and all of its benefits, whilst peripheral labour is usually external and generally associated with the secondary labour force and its lack of benefits. However, Mangum et al. (1985) recognise that many self-employed contractors should be thought of as core employees in the external labour market. This is due to factors such as financial rewards accrued by contractors, level of skill and increased job security factors, and in the case of agricultural contractors, of them often being the only form of labour on a farm. 


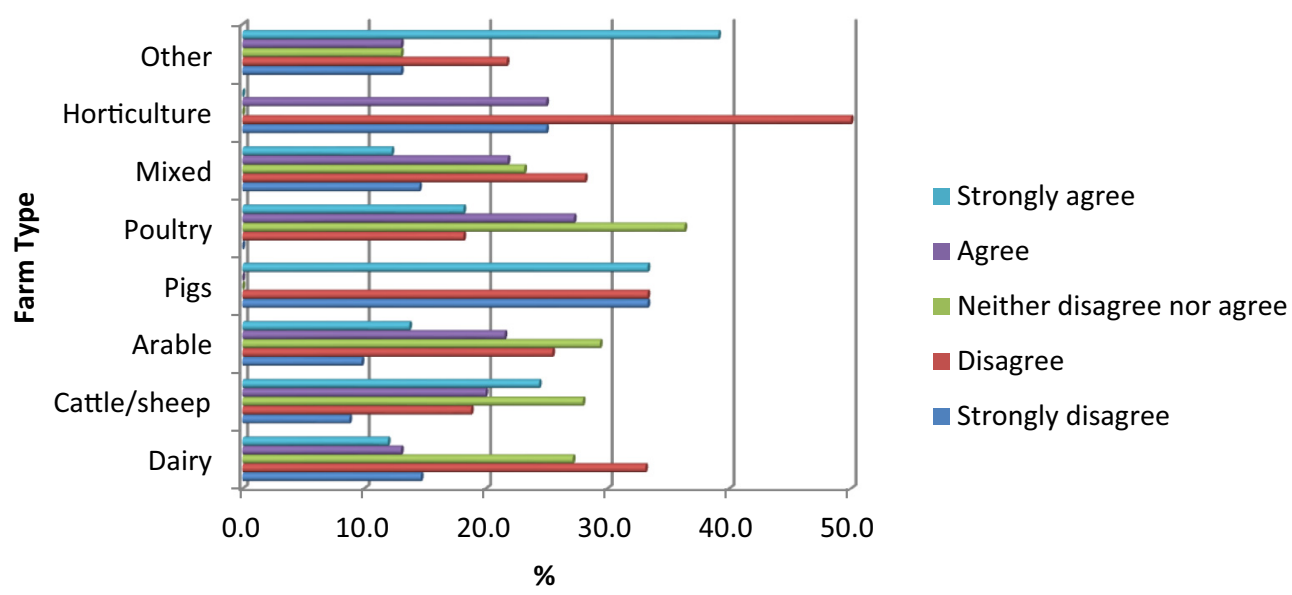

Fig. 1. Extent to which farmers agree with the statement ' $I$ can always find skilled labour when required' by farm type (\%) $(n=750)$. Source: South West Farm Survey.

Fig. 1. Degré d'accord des exploitants avec l'affirmation « Je peux toujours trouver de la main-d'œuvre qualifiée quand j'en ai besoin », par type d'exploitation (\%) $(\mathrm{n}=750)$.

Source: Enquête sur les fermes du Sud-Ouest.

This paper seeks to outline the current labour composition of surveyed farms in the South West, specifically those not the subject of studies to date, that of agricultural contractors and the more permanent workforce.

\section{Method}

Due to the dearth of both recent statistical and sociological research regarding the totality of farm labour in the UK, a mixture of both quantitative and qualitative methods were selected for this study. A survey was executed in the form of a postal questionnaire. The initial sample size for the survey was 4182 with a return of 1251 completed surveys, showing an overall response rate of $29.9 \%$, and producing a good range of responses covering a larger proportion of holdings than many national surveys. The survey did not set out to be representative of all farms in the South West (Fig. 1), but is rather part of a time-series data collection exercise within which questions regarding farm labour were included. The sample was drawn from a database of previous participants in The State of Agriculture survey, initiated in 2004/05 and drawn originally from the Yellow Pages and online directories. It incorporates all types and size-ranges of agricultural holdings within the South West region, 55 per cent of farms were 100 hectares or smaller, with 32 per cent falling in the 100 250 hectares category and almost 13 per cent representing farms of over 250 hectares in size. Dairy, cattle and sheep, and mixed farms were the most represented in the sample, although comparisons with Defra census data demonstrates that larger farms are over-represented in the survey, as are mixed farms (Defra, 2017). Possible reasons for this are that the Defra census measures by holding, whereas the Farm Survey measures by farm.

With regards to the qualitative element of the research, the use of case studies in the form of semi-structured interviews was employed. Between April 2016 and January 2017, a total of 20 farmers, 17 farm workers and 8 contractors were interviewed, selected using non-probability snowball sam- pling. Case study farms ranged from between 200 hectares and 1200 hectares in size, and mixed, dairy, beef and sheep farms were represented. Respondents fell into age ranges between 18 and 92 years old, with women making up $13 \%$ of all respondents (although all contractors were male).

Structured questions concerning basic employment information led to a number of more open-ended questions, attempting to identify labour and employment issues. Contrastingly to the survey technique, 'qualitative interviews [...] explicitly involve the interviewer and respondent in interaction, as interaction partners' (Kelly, 2010: 308).

Participants for both methods were recruited on a voluntary basis with detailed ethical approval provided by the SSIS Ethics Committee.

\section{Results}

\subsection{Composition of labour}

Analysis of the postal survey demonstrates that out of all farms surveyed, $38 \%$ reported employing one or more fulltime workers additional to the labour supplied by the farmer or associated directors, $30 \%$ employ one or more part-time workers, $25 \%$ employ one or more casual staff over the course of the year, $6 \%$ use volunteers and only $4 \%$ employ interns or apprentices. In contrast to these figures, out of all 1251 farms surveyed, $87 \%$ stated that they now use contractors, and this number was consistent across all types of farming system. Contractors are mainly used for the following tasks on the farm, often carrying out one hundred per cent of one of more of these tasks; hedge-cutting, combining, silage-making, ploughing, sowing, drilling, and pesticide application, all jobs which twenty to fifty years ago would have most likely been performed by farm workers.

\subsection{Changes in composition}

Over the last five years, where applicable, $17 \%$ of farms surveyed reported an increase in hired labour, $20 \%$ reported a 
decrease, and $63 \%$ of farmers stated that there was no change in the level of employed labour on their farm over the last five years. It is important to bear in mind that some stating a level of no change might not employ any internal labour at all. With regards to family labour, $18 \%$ of farmers witnessed an increase, $13 \%$ a decrease, and $69 \%$ of farmers stated that there was no change. And finally, $22 \%$ of those surveyed declared an increase in their use of contractors, $11 \%$ a decrease, and $67 \%$ stated that their level of contractors use remained unchanged. These results demonstrate a greater increase in the use of contractors than other forms of labour over the last five years.

Anticipated changes in labour use in the next five years show that $14 \%$ of farmers expect to increase the use of employed labour, $9 \%$ expect to decrease the level of employed labour, and $77 \%$ expect to see no change. Regarding family labour, $11 \%$ of farmers expect to increase the use of family labour, $11 \%$ expect to decrease the level of family labour, and $78 \%$ expect to see no change. A slightly higher frequency of contractor use is expected where $14 \%$ of farmers foresee an increase in their use of contractors, $8 \%$ a decrease, and $78 \%$ expect to see no change.

\subsection{Availability of labour}

Initial figures regarding the availability of labour demonstrate a significant difference between three different types of labour; seasonal, contract (both defined earlier in the paper), and skilled (as perceived by the farmer). The results demonstrate that $78 \%$ of farmers and land managers in the South West, to whom it was applicable, either agree or strongly agree with the statement that 'I can always find contractors when required', whilst seasonal and especially skilled labour prove more difficult to come by. There exists a higher incidence of difficulty in finding skilled labour amongst dairy, horticulture, and mixed farming systems, and on holdings between 100 and 250 hectares in size (Fig. 1).

\subsection{Labour shortages according to respondents}

Several of the farmers interviewed corroborated the above results, stating that they were currently in the process of hiring but described the process as being 'really hard' or a 'struggle'. One stated how:

$$
\begin{aligned}
& \text { "We've tried, we've advertised in the local [agricultural] } \\
& \text { college and things like that but we just can't get anyone." }
\end{aligned}
$$

And even when a suitable candidate is identified, it 'can take between two and four months to get somebody in place' which in an industry such as farming can be debilitating. These shortages in suitably qualified candidates for more permanent positions appear to be a relatively recent phenomenon but farmers are beginning to be fearful of what this might mean for the future of their farms. Several suggested that if a labour crisis were to affect their ability to find workers, they might have to change their system of farming and/or employ more contractors.

Worker retention also proved a problem for numerous farms interviewed and referred to by farmers and workers alike. One reason suggested for this by a farmer was her inability to offer a career ladder to workers:

\begin{abstract}
"It is a real problem to try and get really good farm workers because if they have the intelligence and drive and enthusiasm, they'll take themselves further."
\end{abstract}

While several farmers described few applicants for advertised positions, others stated that where people do apply, many of them lack basic agricultural skills, often despite having attended an agricultural college, and more advanced skills associated with new technologies and machinery are stated, by employers, to be absent in many of the job seeker's skill sets.

Interestingly, this attribution of blame to either applicants or educational establishments was reversed back on to the farmer by several of the more traditional farm workers, citing ineffective people-management techniques, poor allocation of tasks, and lack of career progression as reasons why fewer people want to work on particular farms. Neither pay nor employment stability were referred to by farm workers as being significant issues. Most respondents blamed the poor image of agriculture in this country as well as lack of school education and ill-advised career advice for the lack of new entrants into farming. More than one farm worker describes how they were either directed towards farming at school age, because they were low achievers educationally, or directed away from an agricultural career because they were considered too 'bright'.

"There's lots of non-academic kids that get pushed into agriculture because their teachers think they're too thick to do something else (Farmer)"

The evolution of a final pattern receiving little attention is the role of the agricultural contractor in farming today. The majority of farm businesses of all types are now reliant upon agricultural contractors, a significant source of agricultural labour. One farmer stated that without the existence of contractors, 'it would be impossible to farm' whilst another declared how 'we couldn't run without them'. There is a huge, unexamined network of farm contractors in South West agriculture, many of whom have crossed over from a farm worker or farmer position. Contractors describe themselves as invisible and misunderstood by the government, the public and/or the research agenda, despite their role being pivotal not only for the success of farming but also for employment provision in rural communities. But perhaps most importantly, several contracting businesses declared that they too were beginning to experience difficulties in recruiting staff. This effect has yet to trickle down to the farmers, who report an ease in finding contractors, but is an important signifier as to the lack of suitable entrants into agricultural careers overall.

\section{Discussion}

Three significant patterns emerge from the data. Primarily, survey results mirror the pattern of decline reversal mentioned earlier, demonstrating that not only have numbers of hired farm workers stopped falling, but also that a slight increase is likely in the next five years. The second pattern is the continued increase in contractor use, which is also expected to rise. Such results are encouraging in terms of employment opportunities, but only if such vacancies are likely to be filled; the possibility of which appears slightly more tenuous in the current labour market climate, which leads to the third emergent pattern. 
Aside from well-documented reports of seasonal labour shortages, farmers and employing contractors report increasing difficulty in attracting and/or retaining new workers into permanent, 'skilled' positions. Numerous constraints exist at all levels to the encouragement and retention of new workers into farm work and this now appears to all types of farm work, both core and flexible.

Access to flexible labour including that of contractors is vital to the survival of some farms in the South West of England, a reliance that may increase if shortages in more permanent labour are not addressed. The crucial role played by contractors in the farming industry in the South West complements Mangum et al.'s (1985) (re)definition of contractors as core employees in the external labour market, moving them away from the periphery of Atkinson's (1984) model to, in some cases, replace traditional core workers with some contractors performing most or all of the work on a holding. Yet labour shortages across the board challenge the functional and numerical flexibility benefits usually afforded by the contingent labour market, potentially shifting the larger proportion of labour responsibilities back on to the farmer, or pushing up contracting prices to counter the economic benefits referred to in Errington and Gasson's (1996) theories regarding peripheral labour.

\section{Conclusion}

This paper demonstrates that access to both flexible, intermittent, labour as well as more permanent hired labour is key to the future of agriculture in the South West. Considerable emphasis has, in the current political climate, been placed upon the lack of availability of seasonal, mainly migrant, workers. In drawing the focus away from other actors contributing to labour on South West farms, as well as farms in other UK regions, the afore-mentioned patterns in farm labour composition and availability have been overlooked. Future research is needed to ascertain the scale of flexibility occurring in the rest of the country, as well as seeking to identify and understand labour shortages in farming on a national scale, inclusive of all types of worker, not just seasonal labour. There is a significant need for an update of research concerning the UK's agricultural workforce in line with that already occurring in New Zealand and Australia.

\section{References}

Atkinson J. 1984. Manpower strategies for flexible organisations. Personnel Management 16(8): 28-31.

Ball RM. 1987a. Agricultural contractors: some survey findings. Journal of Agricultural Economics 38(3): 481-488.

Ball RM. 1987b. Intermittent labour forms in UK agriculture: some implications for rural areas. Journal of Rural Studies 3(2): $133-150$.

Body R. 1983. Agriculture: The triumph and the shame. London: Temple Smith.

Brookfield H. 2008. Family farms are still around: time to invert the old agrarian question. Geography Compass 2(1): 108-126.

Defra. 2013. Future of farming review report. London: Defra. Available from https://www.gov.uk/government/uploads/system/ uploads/attachment_data/file/211175/pb13982-future-farming-re view-20130709.pdf [Accessed 3rd January 2016]

Defra. 2014. Agriculture in the United Kingdom. London: Defra. Available from https:/www.gov.uk/government/uploads/system/ uploads/attachment_data/file/430411/auk-2014-28may15a.pdf [Accessed 11th March 2016]

Defra. 2015. 'Annual time series: 1983 to 2015 -Labour'. Structure of the agricultural industry in England and the UK at June. London: Defra. Available from https://www.gov.uk/government/statisticaldata-sets/structure-of-the-agricultural-industry-in-england-andthe-uk-at-june [Accessed 3rd March 2016]

Defra. 2017. Detailed annual statistics on the structure of the agricultural industry at 1 June in England and the UK. [Online]. London: Defra. Available from https:/www.gov.uk/government/ statistical-data-sets/structure-of-the-agricultural-industry-in-eng land-and-the-uk-at-june [Accessed 24th March 2017]

Devlin S. 2016. Agricultural labour in the UK. London: Food Research Collaboration.

Errington A, Gasson R. 1996. The increasing flexibility of the farm and horticultural workforce in England and Wales. Journal of Rural Studies 12(2): 127-141.

Gasson R, Errington A. 1993. The Farm Family Business. Wallingford: Cab International.

Geddes A, Scott S. 2011. 'UK Food Businesses' reliance on low-wage migrant labour: a case of choice or constraint? In: Ruhs M, Anderson B, eds. Who needs migrant workers?: Labour shortages, immigration and public policy. Oxford: Oxford Scholarship Online.

Holderness BA. 1985. British agriculture since 1945. UK: Manchester University Press.

Igata M, Hendrikson A, Heijman W. 2008. Agricultural outsourcing: a comparison between the Netherlands and Japan. Applied Studies in Agribusiness and Commerce 2(1): 29-33.

Kelly SE. 2010. Qualitative interviewing techniques and styles. In: Bourgeault I, Dingwall R, de Vries R, eds. The SAGE handbook of qualitative methods in health research. London: Sage.

Lobley M, Potter C. 2004. Agricultural change and restructuring: recent evidence from a survey of agricultural households in England. Journal of Rural Studies 20(4): 499-510.

Lobley M, Potter C, Butler A, Whitehead I, Millard N. 2005. The wider social impacts of changes in the structure of agricultural businesses. Centre for Rural Research, University of Exeter.

Mangum G, Mayall D, Nelson K. 1985. The temporary help industry: a response to the dual internal labour market. Industrial and Labor Relations Review 38(4): 599-611.

Morrison J, Hine R, Pretty J. 2005. Survey and analysis of labour on organic farms in the UK and Republic of Ireland. International Journal of Agricultural Sustainability 3(1): 24-43.

Mort M, Convery I, Baxter J, Bailey C. 2005. Psychosocial effects of the 2001 UK foot and mouth disease epidemic in a rural population: qualitative diary based study. BMJ 331(7527): 1234

Nettle R. 2015. More than workforce shortages: How farm human resources management strategies will shape Australia's agricultural future. Farm Policy Journal 12(2): 17-27.

NFU. 2015. Compete to grow. A vision and strategy for the British dairy industry. Available from http://www.nfuonline.com/nfudairy-strategy-compete-to-grow/ [Accessed 13th March 2016]

Parry J, Barnes H, Lindsey R, Taylor R. 2005. Farmers, farm workers and work-related stress. Prepared by Policy Studies Institute for the Health and Safety Executive, Research Report 362.

Peel S, Boxall P. 2005. When is contracting preferable to employment? An exploration of management and worker perspectives. Journal of Management Studies 42: 0022-2380. 
Scott S. 2007. Temporary migrant workers and the UK's flexible labour market: shifting policy narratives and regulatory rebalancing. Migration Control and Narratives of Societal Steering. The University of Edinburgh.
Tipples R, Morriss S. 2002. The farm labour crisis - A problem for the new millennium? In: Proceedings (Volume 2), Conference of the Association of Industrial Relations Academics of Australia and New Zealand, 6-8 February, pp. 257-266.

Cite this article as: Nye C. 2018. The 'blind spot' of agricultural research: Labour flexibility, composition and worker availability in the South West of England. Cah. Agric. 27: 35002. 